\title{
Investigasi Kemampuan Problem Solving dan Problem \\ Posing Matematis Mahasiswa via Pendekatan Realistic
}

\author{
The InVEstigation of Students' Mathematical Problem Solving and \\ Problem Posing SKILLS VIa REALISTIC APPROACH
}

\author{
Ekasatya Aldila Afriansyah \\ Pendidikan Matematika, STKIP Garut \\ Garut, Jawa Barat, Indonesia \\ essatya@yahoo.com
}

\begin{abstract}
Abstrak
Kemampuan problem solving dan problem posing matematis merupakan kemampuan matematis yang perlu dimiliki oleh mahasiswa. Melalui kedua kemampuan ini, seorang mahasiswa dapat lebih kreatif dalam mengungkapkan ide serta gagasannya dengan cara menghubungkan pengetahuan yang dia peroleh sebelumnya dan mengaitkannya dengan pengetahuan yang dia diperoleh sekarang; serta mampu menuangkan gagasan/ide dalam menyelesaikan persoalan matematis yang dihadapinya. Namun pada kenyataannya, masih banyak mahasiswa yang belum memiliki kedua kemampuan ini, sehingga perlu diadakan perbaikan pembelajaran melalui pendekatan yang tepat. Pada penelitian ini, pendekatan pembelajaran yang dijadikan sebagai solusinya adalah pendekatan Realistic. Penelitian ini bertujuan untuk mengetahui peningkatan kemampuan problem solving dan problem posing matematik mahasiswa melalui pendekatan Realistic. Metode penelitian yang digunakan pada penelitian ini adalah metode kuantitatif. Instrumen yang digunakan pada penelitian ini berupa tes diagnostik berupa pre-test dan pos-test, dan angket. Hasil dari penelitian ini, kemampuan problem solving dan problem posing mahasiswa cenderung meningkat. Rekomendasi bagi peneliti lain adalah melakukan penelitian sejenis ini dengan subjek penelitian yang berbeda, seperti mahasiswa calon guru.
\end{abstract}

Kata Kunci: Kemampuan problem solving matematis, Kemampuan problem posing matematis, pendekatan Realistic, metode kuantitatif.

\begin{abstract}
Mathematical problem solving and problem posing skill are the mathematical skills that need to be owned by students. By having this skill, students can be more creative in expressing ideas by connecting the knowledge that they held previously. But in reality, there are some students who are lack of problem solving skill; therefore it is really important to improve learning through appropriate approach. Realistic approach had been chosen as the learning theory to be applied in the class. This study has the objective to find out whether the use of realistic approach enhances students' mathematical problem solving and problem posing skills. The research methodology used in this study is a quantitative research. The instrument used diagnostic tests (pre-test and post-test); and questioner. The results of this study, the mathematical problem solving and problem posing skills students tend to increase. Recommendations for other researchers are do the research of mathematical problem solving and problem posing skills in other populations, especially prospective teachers.
\end{abstract}

Keyword: Mathematical problem solving skill, mathematical problem posing skill, Realistic approach, quantitative research. 


\section{Pendahuluan}

G. Thompson menyatakan bahwa "Pendidikan adalah pengaruh lingkungan atas individu untuk menghasilkan perubahan-perubahan yang tetap di dalam kebiasaan-kebiasaan, pemikiran, sikapsikap dan tingkah laku." Sama halnya dengan Crow dan Crow mengemukakan "Fungsi utama pendidikan adalah bimbingan terhadap individu dalam upaya memenuhi kebutuhan dan keinginan yang sesuai dengan potensi yang dimilikinya." [1]

Dalam Kurikulum Tingkat Satuan Pendidikan (KTSP), matematika memiliki peranan penting dalam pembentukan pola pikir serta dalam menyelesaikan masalah. Adapun tujuan pembelajaran matematika yang tercantum dalam KTSP antara lain agar mahasiswa memiliki kemampuan: 1) Memahami konsep matematika, 2) Menggunakan penelaran pada pola dan sifat, 3) Memecahkan masalah yang meliputi kemampuan memahami masalah merancang model matematik, 4) Mengkomunikasikan gagasan dengan simbol, dan 5) Memiliki sikap menghargai kegunaan matematika dalam kehidupan.

Berdasarkan dari tujuan pendidikan matematika di atas, kemampuan dalam pemecahan masalah sangat diperlukan mahasiswa. Dalam proses pemecahan masalah mahasiswa dapat menemukan permasalahan yang berdasarkan pada pengamatan, mengidentifikasi masalah yang kemudian akan menghubungkan informasi yang diperoleh dengan informasi yang telah didapat sebelumnya.

Selain itu, kemampuan dalam pengajuan masalah (problem posing) pun tidak kalah pentingnya harus dimiliki mahasiswa. Hal ini dikarenakan ketika seorang mahasiswa menemukan permasalahan baru, maka akan memunculkan pertanyaan baru sehingga mahasiswa harus merumuskan masalah atau mengajukan masalah sesuai dengan situasi yang disajikan.

Namun pada kenyataannya, dilihat dari beberapa penelitian sebelumnya, kemampuan pemecahan masalah dan kemampuan pengajuan masalah masih rendah. Semua itu adalah akibat dari kebiasaan dosen melakukan langkah pembelajaran yang masih bersifat konvensional sebagai berikut: (1) dosen menerangkan suatu konsep atau mendemontrasikan keterampilan dengan cara ceramah, dan mahasiswa diberikan kesempatan bertanya; (2) dosen memberikan contoh penggunaan konsep dan prosedur dalam menyelesaikan persoalan; (3) mahasiswa berlatih menyelesaikan soal secara individu atau teman sebangku, dan sedikit dalam melakukan tanya jawab; (4) mahasiswa mencatat materi yang diajarkan dan soalsoal pekerjaan rumah (PR).

Untuk mengatasi permasalahan tersebut perlu dilakukan perubahan pendekatan dalam pembelajaran. Peneliti memandang terdapat pendekatan yang sesuai untuk digunakan, yaitu pendekatan Realistic atau umumnya dikenal dengan nama Pendidikan Matematika Realistik Indonesia (PMRI). Dari pendekatan tersebut memungkinkan mahasiswa dapat meningkatkan kreatifitasnya dalam mengajukan masalah (problem posing) dalam menyelesaikan masalah matematik. 
Berdasarkan uraian di atas, peneliti berencana untuk melakukan penelitian dengan judul "Investigasi Kemampuan Problem Solving dan Problem Posing Matematis Mahasiswa via Pendekatan Realistic"

Rumusan masalah di dalam penelitian ini adalah:

a. Bagaimana pengaruh pendekatan Realistic terhadap kemampuan mathematical problem solving dan mathematical problem posing mahasiswa?

b. Apakah interpretasi sikap mahasiswa terhadap pembelajaran dengan menggunakan pendekatan Realistic?

Sumarmo mengemukakan bahwa pandangan pemecahan masalah sebagai proses, merupakan suatu kegiatan yang lebih mengutamakan kepada pentingnya prosedur, langkah-langkah, strategi dan heuristik yang ditempuh mahasiswa dalam menyelesaikan masalah, sehingga dapat menemukan jawaban soal dan bukan hanya pada jawaban itu sendiri [2]. Sedangkan pemecahan masalah sebagai kemampuan dasar merupakan jawaban yang sangat kompleks, bahkan lebih kompleks dari pengertian pemecahan masalah itu sendiri.

Dalam menyelesaikan masalahnya mahasiswa diharapkan mampu untuk memahami masalah tersebut, sehingga dapat membuat rencana dan proses dalam menyelesaikan masalah secara tepat. Maher menggungkapkan bahwa salah satu komponen pemecahan masalah adalah representasi, yakni merepresentasikan ideide matematik yang berkaitan dengan masalah secara ringkas dan sederhana sehingga mudah untuk diolah dan dioperasikan serta dicari solusinya. [3]

Dalam kegiatan pembelajaran sangatlah penting bagi mahasiswa mempunyai kemampuan pemecahan masalah. Branca mengungkapkan alasan mengenai pentingnya pemecahan masalah, diantaranya: (1) Kemampuan pemecahan masalah merupakan tujuan umum pengajaran matematika, bahkan sebagai jantungnya matematika, (2) pemecahan masalah dapat meliputi metode, prosedur dan strategi atau cara yang digunakan merupakan proses inti dan utama dalam kurikulum matematika, dan (3) pemecahan masalah merupakan kemampuan dasar dalam belajar matematika. Dengan pembelajaran melalui pemecahan matematika mahasiswa akan mempunyai kemampuan dalam menganalisis dan merancang strategi-strategi penyelesaian untuk masalah-masalah selanjutnya. [4]

Rhodes membedakan pengertian kreativitas dalam empat dimensi, yaitu: (1) person, (2) process, (3) product, dan (4) press. Dalam pengertian dimensi seseorang adalah seseorang yang menghasilkan prestasi kreatif ditentukan oleh bakat dan afektif, bakat yang meliputi kelancaran, kelenturan, keluwesan dan originalitas sedangkan afektif meliputi kepercayaan diri, keuletan dan kemandirian. [5]

Sangatlah penting seorang mahasiswa mempunyai kemampuan kreatif dalam memecahkan masalah matematik. Hamzah menyatakan seorang individu yang kreatif memiliki rasa keingitahuan yang tinggi, menikmati tantangan, optimis, memandang masalah sebagai kesempatan, 
tidak mudah menyerah dan bekerja keras [6]. Hal ini tentu saja diperlukan seorang mahasiswa dalam menyelesaikan masalah matematik.

Selain itu kemampuan kreatif mahasiswa tidak hanya diperlukan dalam menyelesaikan masalah, akan tetapi dalam pengajuan persoalan (problem posing) dalam kegiatan pembelajaran. Hal ini sejalan dengan Ellerton dan Clarkson yang menyatakan bahwa "Pentingnya pemilikan kemampuan mathematical problem posing terlukis dalam pernyataan bahwa pengembangan kemampuan matematik membutuhkan kemampuan berimaginasi kreatif matematik. [7]

Pentingnya seorang mahasiswa memiliki kemampuan problem posing tertuang dalam [8] yang menganjurkan bahwa mahasiswa harus dilatih dalam merumuskan masalah atau pertanyaan sesuai dengan situasi yang disajikan baik di dalam ataupun di luar matematika.

Pendekatan Realistic yang dimaksudkan dalam penelitian ini adalah Pendidikan Matematika Realistik Indonesia (PMRI). PMRI merupakan adaptasi dari RME (Realistic Mathematics Education) yaitu sebuah teori pembelajaran yang dikembangkan di Belanda sejak tahun 1970-an oleh Hans Freudhental. Dalam PMRI, permasalahan realistik digunakan sebagai fondasi dalam membangun konsep matematika. Kebermaknaan konsep matematika merupakan konsep utama dari PMRI. Proses belajar mahasiswa hanya akan terjadi jika pengetahuan (knowledge) yang dipelajari bermakna bagi mahasiswa.
Terdapat dua pandangan yang penting dari Hans Freudhental yaitu (1) mathematics must be connected to reality; and (2) mathematics as human activity" [9]. Pandangan pertama bahwa matematika itu harus dekat dengan mahasiswa dan sesuai dengan situasi kehidupan sehari-hari yang dialami mahasiswa. Pandangan kedua mempunyai makna bahwa matematika merupakan suatu aktivitas manusia dimana mahasiswa diberikan suatu kesempatan untuk belajar di dalam aktivitas matematika.

a. Prinsip Utama PMRI [10]

Freudhental terdapat tiga prinsip dalam pembelajaran matematika realistik yang digunakan sebagai landasan dalam merancang pembelajaran (instructional design) yang kemudian diadopsi menjadi prinsip utama PMRI, yaitu: 1) Penemuan terbimbing dan bermatematika secara progresif, 2) Fenomena mendidik, dan 3) Model pengembangan mandiri.

b. Karateristik PMRI [11]

Gravemeijer menyatakan bahwa ada lima karateristik RME yang diadopsi menjadi karateristik PMRI, yaitu: 1) Penggunaan masalah kontekstual, 2) Penggunaan model, 3) Penggunaan produk jawaban dari mahasiswa sendiri, 4) Interaktivitas, dan 5) Terintegrasi dengan topik lainnya.

c. Pengembangan Model [12]

Pada pendekatan ini, model digunakan sebagai jembatan bagi mahasiswa yang menghubungkan situasi riil ke matematika formal. Pengembangan model digambarkan sebagai suatu proses perubahan dari model-of menjadi modelfor. Sejalan dengan prinsip reinvention, mahasiswa mengkonstruk sendiri 
modelnya. Dalam hal ini, mahasiswa diberikan kesempatan untuk menggunakan dan mengembangkan modelnya sendiri ketika menyelesaikan masalah.

\section{Metode}

Jenis penelitian ini adalah penelitian kuantitatif, berbentuk kuasi eksperimen dengan desain "Kelompok Kontrol NonEkivalen". Dimana subjek tidak dikelompokkan secara acak, menerima keadaan subjek apa adanya. Penelitian dilakukan pada satu kelas yang memiliki mahasiwa dengan kemampuan heterogen. Kelompok kelas ini dinamakan kelompok kelas eksperimen; diberikan pembelajaran dengan menggunakan pendekatan Realistic dengan desain penelitian sebagai berikut:

Eksperimen : $\mathrm{O}$ X $\mathrm{O}$

dengan,

$\mathrm{O}$ : Pretest dan posttest kemampuan mathematical problem solving dan mathematical problem posing

$\mathrm{X}$ : Perlakuan dengan pendekatan

Realistic

Subjek dalam penelitian ini adalah mahasiswa tingkat I, Jurusan Teknik Sipil dalam mata kuliah Matematika 2 (Kalkulus) di Institut Teknologi Nasional (ITENAS).

Penelitian ini dilakukan menggunakan desain eksperimen dengan pre-test, perlakuan, dan post-test. Pembelajaran sendiri dilaksanakan melalui kelas eksperimen dan kelas kontrol. Kelas eksperimen menggunakan pendekatan Realistic sedangkan kelas kontrol menggunakan pendekatan tradisional dengan metode ceramah. Kemudian kemampuan problem solving dan problem posing matematis mahasiswa dari dua kelas tersebut dibandingkan menggunakan uji kesimpulan kenormalitasan data, jika data kelas eksperimen dan kelas kontrol berdistribusi normal diteruskan dengan uji homogenitas. Apabila kedua data homogen maka dilanjutkan dengan uji $t$ tetapi jika tidak homogen maka dilanjutkan dengan uji t'. Akan tetapi apabila ada salah satu data yang tidak berdistribusi normal maka dilanjutkan dengan uji Mann Whitney dan uji hipotesis akhir ditarik apakah hipotesisnya diterima atau ditolak melalui pendekatan Realistic.

Teknik pengumpulan data dalam penelitian ini antara lain:

a. Survei

Dilakukan dengan mengumpulkan data nilai mahasiswa sebelumnya sebagai bahan pertimbangan untuk menentukan kelas penelitan sehingga dianggap kelas tersebut mempunyai kemampuan yang sama.

b. Tes diagnostik

Tes ini dilakukan melalui dua tahap yaitu pre-test dan post-test.

c. Pelaksanaan Penelitian

Pada tahap ini peneliti melakukan pembelajaran pada satu kelas eksperimen dengan menggunakan pendekatan Realistic.

d. Angket

Tahapan ini dimaksudkan untuk mengetahui tanggapan dan sikap mahasiswa terhadap pembelajaran selama penelitian.

Teknik analisis data yang digunakan dalam penelitian ini adalan analisis 
kuantitatif. Analisis kuantitatif adalah penelaahan butir soal didasarkan pada data empirik dari butir soal yang bersangkutan, yaitu dengan cara mencari validitas, realibilitas, daya pembeda dan tingkat kesukaran soal.

\section{Hasil dan Pembahasan}

Penelitian ini bertujuan untuk mengetahui hasil penerapan pendekatan Realistic terhadap kemampuan problem solving dan problem posing matematis mahasiswa di salah satu institusi swasta di Bandung.

\section{A. Mathematical Problem Solving}

Pelaksanaan pre-test dilakukan oleh kelas eksperimen maupun kelas kontrol. Pre-test terdiri dari 3 soal uraian yang harus dikerjakan mahasiswa selama 60 menit. Mahasiswa mengerjakan secara individual dan setelah selesai kemudian dikumpulkan untuk diperiksa. Analisis data tes awal (Pre-test) yang diperoleh dari kelas eksperimen dan kelas kontrol bertujuan untuk mengetahui kemampuan awal mahasiswa sebelum diberi perlakuan atau pembelajaran. Data hasil pre-test yang telah dilakukan pada kedua kelas penelitian, yaitu kelas A sebagai kelas eksperimen dan B sebagai kelas kontrol.

Hasil dari pengolahan uji normalitas, data kelas eksperimen dan data kelas kontrol menghasilkan sebaran data yang tidak berdistribusi normal. Maka uji statistik selanjutnya menggunakan Uji Mann Whitney yang digunakan untuk menguji perbedaan rata-rata dari dua kelompok sampel saling bebas.
Dari perhitungan tes awal antara kelas eksperimen dan kelas kontrol menggunakan uji dua pihak dan taraf signifikan 0,05 diperoleh nilai $Z_{\text {hitung }}=$ 2,06 dan $\mathrm{Z}_{\text {tabel }}=1,96$. Karena berada pada daerah penerimaan Ho yaitu: $Z_{\text {hitung }}>$ $\mathrm{Z}_{\text {tabel}}$, maka Ho diterima dan Ha ditolak.

Dengan demikian, dapat disimpulkan bahwa dari data hasil pre-test kedua kelas penelitian tersebut menyatakan Ho diterima, dengan kata lain tidak perbedaan kemampuan awal problem solving matematis mahasiswa antara kelas yang akan mendapatkan pendekatan Realistic dan yang akan mendapatkan pendekatan tradisional.

Pada hasil analisis data tes akhir (posttest) yang bertujuan untuk mengetahui kemampuan akhir problem solving mahasiswa setelah diberikan perlakuan atau pembelajaran. Setelah data terkumpul, lalu peneliti memperoleh hasil sebagai berikut:

Tabel 1.

Rekapitulasi Hasil Perhitungan Uji $t$

\begin{tabular}{ccccc}
\hline Kelas & $\begin{array}{c}\text { Jumlah } \\
\text { Mahasiswa }\end{array}$ & Varians & $\mathbf{t}_{\text {hitung }}$ & $\mathbf{t}_{\text {tabel }}$ \\
\hline Eksperimen & 40 & 125,94 & \multirow{2}{*}{3,03} & 1,66 \\
\hline Kontrol & 40 & 281,99 & & \\
\hline
\end{tabular}

Hal ini menunjukan Ho ditolak dikarenakan $\mathrm{t}_{\text {hitung }}=3,03>\mathrm{t}_{\text {tabel }}=1,66$. Dengan demikian dari kedua pengujian dapat disimpulkan bahwa kemampuan problem solving matematis mahasiswa antara kelas yang mendapatkan pendekatan Realistic lebih baik dibandingkan dengan yang mendapatkan pendekatan tradisional. 


\section{B. Mathematical Problem Posing}

Analisis data tes awal (pre-test) diperoleh dari mahasiswa yang mendapatkan pendekatan Realistic dan mahasiswa yang mendapatkan pendekatan tradisional. Tes awal dilakukan untuk mengetahui kemampuan awal mahasiswa sebelum diberikan pembelajaran, baik untuk kelas eksperimen maupun untuk kelas kontrol. Setelah data yang diperlukan dalam penelitian ini lengkap, selanjutnya peneliti melakukan pengolahan data tes awal berdasarkan langkah-langkah pengolahan data.

Karena salah satu data tidak berdistribusi normal yaitu data pada kelas kontrol, maka langkah selanjutnya adalah Uji Mann Whitney yang berguna untuk menguji perbedaan kemampuan awal kelas eksperimen dan kelas kontrol.

Setelah dilakukan perhitungan, diperoleh nilai $Z_{\text {hitung }}=2,01$. Dengan menggunakan taraf signifikansi sebesar $5 \%$ sehingga diperoleh nilai $z_{\text {tabel }}=1,96$. Dengan kriteria terima Ho jika $-z_{\text {tabel }}<$ $z_{\text {hitung }}<z_{\text {tabel }}$. Sehingga kesimpulannya adalah Ho ditolak, maka terdapat perbedaan kemampuan awal yang signifikan antara mahasiswa yang akan mendapatkan pendekatan Realistic dan mahasiswa yang akan mendapatkan pendekatan tradisional.

Analisis data tes akhir (post-test) yang diperoleh dari kelas eksperimen dan kelas kontrol bertujuan untuk menganalisis perbandingan kemampuan akhir mahasiswa setelah diberikan perlakuan atau pembelajaran. Setelah data terkumpul, lalu peneliti melakukan pengolahan data sesuai dengan langkahlangkahnya.

Karena salah satu data tidak berdistribusi normal yaitu kelas kontrol, maka langkah selanjutnya adalah Uji Mann Whitney yang berguna untuk menguji perbandingan kemampuan matematis mahasiswa setelah diberikan perlakuan antara kelas eksperimen dan kelas kontrol.

Setelah dilakukan perhitungan, didapat nilai $\mathrm{z}_{\text {hitung }}=2,36$. Dengan menggunakan taraf signifikansi sebesar 5\% sehingga diperoleh nilai $\mathrm{z}_{\text {tabel }}=1,96$. Dengan uji satu pihak dan kriteria terima Ho jika $z_{\text {hitung }} \leq z_{\text {tabel }}$. Sehingga kesimpulannya adalah Ho ditolak, dan dapat disimpulkan bahwa Kemampuan problem posing matematis mahasiswa yang mendapatkan pendekatan Realistic lebih baik dibandingkan dengan pendekatan tradisional.

\section{Indikator Peningkatan Kemampuan}

Analisis data gain ternormalisasi ini bertujuan untuk mengetahui indikator peningkatan kemampuan problem solving matematis mahasiswa. Besarnya peningkatan sebelum dan sesudah pembelajaran dihitung dengan rumus gain ternormalisasi.

Untuk mengetahui seberapa besar indicator peningkatan kemampuan problem solving matematis mahasiswa dari hasil perhitungan dapat dilihat pada tabel 2 berikut ini: 
Tabel 2.

Deskripsi Data Gain Ternormalisasi

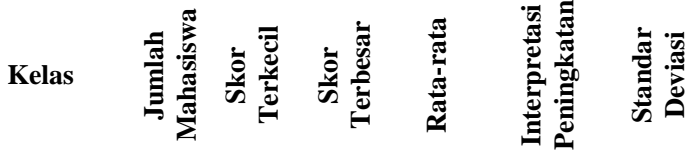

\begin{tabular}{lllllll}
\hline Eksperimen & 40 & 0,25 & 0,94 & 0,57 & Sedang & 0,19
\end{tabular}

$\begin{array}{llllllll}\text { Kontrol } & 40 & 0,00 & 0,73 & 0,40 & \text { Sedang } & 0,18\end{array}$

Dari hasil penelitian data di atas terlihat bahwa gain ternormalisasi yang diperoleh dari kelas eksperimen yaitu banyaknya jumlah mahasiswa 40 orang dengan skor terkecil gain ternormalisasi 0,25 dan skor terbesar 0,94, sehingga diperoleh nilai rata-rata gain ternormalisasi 0,57, simpangan bakunya 0,19 dan interpretasi peningkatannya tergolong sedang. Sedangkan hasil dari kelas kontrol yaitu banyaknya jumlah mahasiswa 40 orang dengan skor terkecil gain ternormalisasi 0,00 dan skor terbesar 0,73, sehingga diperoleh rata-rata gain ternormalisasi 0,40 simpangan bakunya 0,18 dan interpretasi peningkatannya tergolong sedang.

Sementara itu, besar peningkatan kemampuan problem posing matematis mahasiswa dari hasil perhitungan untuk kelas eksperimen dan kelas kontrol dapat dilihat pada tabel 3 berikut.

Tabel 3.

Deskripsi Data Gain Ternormalisasi

\begin{tabular}{|c|c|c|c|c|c|}
\hline Kelas & 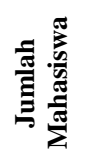 & 离总 & 离 & 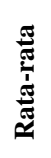 & 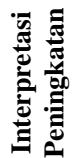 \\
\hline
\end{tabular}

\begin{tabular}{|ccccccc|}
\hline Eksperimen & 40 & 0,24 & 1,00 & 0,64 & Sedang & 0,24 \\
\hline Kontrol & 40 & 0,16 & 0,95 & 0,40 & sedang & 0,16 \\
\hline
\end{tabular}

Dari hasil penelitian data di atas, terlihat bahwa gain ternormalisasi yang diperoleh dari kelas eksperimen yaitu banyaknya jumlah mahasiswa 40 orang dengan skor terkecil gain ternormalisasi 0,24 dan skor terbesar 1,00, sehingga diperoleh nilai rata-rata gain ternormalisasi 0,64. Oleh karena itu interpretasi peningkatannya tergolong sedang. Sedangkan hasil dari kelas kontrol yaitu banyaknya jumlah mahasiswa 40 orang dengan skor terkecil gain ternormalisasi 0,16 dan skor terbesar 0,95, sehingga diperoleh rata-rata gain ternormalisasi 0,40. Oleh karena itu interpretasi peningkatannya tergolong sedang.

\section{Interpretasi Sikap Mahasiswa}

Angket ini diberikan kepada kelas eksperimen dan digunakan untuk menelaah sikap mahasiswa terhadap pembelajaran matematika dengan menggunakan pendekatan Realistic. Peneliti membuat angket tertulis yang terdiri dari 30 pernyataan. Dari 30 pernyataan tersebut terdiri dari 17 pernyataan positif dan 13 pernyataan negatif.

Pada penelitian ini, peneliti membahas mengenai analisis interpretasi skala sikap mahasiswa secara umum dengan menggunakan pendekatan Realistic dan pernyataan yang berkaitan dengan problem solving dan problem posing. Analisis selengkapnya untuk lampiran sikap mahasiswa dapat dilihat pada lampiran. Dalam perhitungan setiap interpretasi terlebih dahulu kita harus menentukan nilai maksimum, nilai minimum, rentang, panjang kelas dan skala tanggapan.

Pada skala sikap diperoleh nilai maksimum 5200, nilai minimum 1040, 
rentang 4160 dan panjang kelas 832 sehinggap didapat skala tanggapan. Berikut tabel 4 yang merupakan skala tanggapan secara umum, yaitu:

Tabel 4.

Skala Tanggapan secara umum yang diperoleh

\begin{tabular}{cc|}
\hline Skor Total $($ ST) & Interpretasi \\
\hline $1040 \leq \mathrm{ST}<1872$ & Sangat Jelek \\
\hline $1872 \leq \mathrm{ST}<2704$ & Jelek \\
\hline $2704 \leq \mathrm{ST}<3536$ & Cukup \\
\hline $3536 \leq \mathrm{ST}<4408$ & Baik \\
\hline $4408 \leq \mathrm{ST}<5200$ & Sangat Baik
\end{tabular}

Rekapitulasi interprestasi sikap mahasiswa secara keseluruhan dapat dilihat pada tabel 5 berikut ini:

Tabel 5.

Rekapitulasi Interpretasi Sikap Secara Umum Mahasiswa Kelas Eksperimen

\begin{tabular}{ccc|}
\multicolumn{3}{c}{ Mahasiswa Kelas Eksperimen } \\
\hline Sikap & $\begin{array}{c}\text { Jumlah } \\
\text { Skor } \\
\text { Total }\end{array}$ & $\begin{array}{c}\text { Interpretasi } \\
\text { Sikap } \\
\text { Mahasiswa }\end{array}$ \\
\hline $\begin{array}{c}\text { Sikap mahasiswa terhadap } \\
\text { matematika }\end{array}$ & & \\
\hline $\begin{array}{c}\text { Sikap mahasiswa terhadap } \\
\text { Pembelajaran dengan menggunakan } \\
\text { Pendekatan Realistic }\end{array}$ & 3914 & Baik \\
\cline { 1 - 1 } $\begin{array}{c}\text { Sikap mahasiswa terhadap soal-soal } \\
\text { problem solving }\end{array}$ & & \\
\hline $\begin{array}{c}\text { Sikap mahasiswa terhadap soal-soal } \\
\text { problem posing }\end{array}$ & & \\
\hline
\end{tabular}

Dari tabel 5 terlihat bahwa jumlah skor total kelas eksperimen adalah sebesar 3914. Jumlah skor total didapat dari jumlah skor tiap pernyataan, baik penyataan positif maupun pernyataan negatif. Jumlah skor total 3914 terdapat pada rentang skala tanggapan 3536-4408. Jadi interpretasi sikap mahasiswa secara umum pada kelas eksperimen mengenai sikap mahasiswa terhadap pembelajaran matematika dengan menggunakan pendekatan Realistic dan terhadap persoalan problem solving dan problem posing matematis berinterpretasi baik.

Setiap indikator mempunyai skala tanggapan yang berbeda-beda. Pada angket ini terdapat empat indikator dan pada masing-masing indikator diwakili oleh beberapa pernyataan. Berikut merupakan data skala tanggapan mahasiswa dilihat dari setiap indikatornya:

Tabel 6.

Rekapitulasi Interpretasi Sikap tiap Indikator pada Kelas Eksperimen

\begin{tabular}{cccc|}
\hline $\begin{array}{c}\text { Sikap } \\
\text { Mahasiswa }\end{array}$ & $\begin{array}{c}\text { No } \\
\text { pernyataan }\end{array}$ & $\begin{array}{c}\text { Jumlah } \\
\text { Skor Total }\end{array}$ & $\begin{array}{c}\text { Interpretasi } \\
\text { Sikap } \\
\text { Mahasiswa }\end{array}$ \\
\hline $\begin{array}{c}\text { Terhadap } \\
\text { Matematika }\end{array}$ & $\begin{array}{c}1,7,11, \\
\text { dan 23 }\end{array}$ & 655 & Baik \\
\hline $\begin{array}{c}\text { Terhadap } \\
\text { pembelajaran } \\
\text { Pendekatan } \\
\text { Realistic }\end{array}$ & $\begin{array}{c}3,4,10,12, \\
14,16,18, \\
20,25, \text { dan } \\
26\end{array}$ & 1567 & Baik \\
\hline $\begin{array}{c}\text { Terhadap soal- } \\
\text { soal Problem } \\
\text { Solving }\end{array}$ & $\begin{array}{c}5,8,9,15, \\
17, \text { dan 21 }\end{array}$ & 825 & Baik \\
\hline $\begin{array}{c}\text { Terhadap soal- } \\
\text { soal Problem } \\
\text { Posing }\end{array}$ & $\begin{array}{c}2,6,13,19, \\
22, \text { dan } 24\end{array}$ & 867 & Baik \\
\hline
\end{tabular}

Dari tabel 6 diperoleh kesimpulan sebagai berikut:

Pada indikator yang menunjukkan sikap mahasiswa terhadap matematika ada 4 pernyataan. Diantaranya pernyataan 1 berjumlah 158, pernyataan 7 berjumlah 154, pernyataan 11 berjumlah 165 , dan pernyataan 23 berjumlah 178, sehingga menghasilkan skor total sebesar 655 .

Tabel 7.

Skala Tanggapan terhadap Matematika

\begin{tabular}{|cc|}
\hline \multicolumn{1}{c}{ Skor Total (ST) } & Interpretasi \\
\hline $160 \leq \mathrm{ST}<288$ & Sangat Jelek \\
\hline $288 \leq \mathrm{ST}<416$ & Jelek \\
\hline $416 \leq \mathrm{ST}<544$ & Cukup \\
\hline $544 \leq \mathrm{ST}<672$ & Baik \\
\hline $672 \leq \mathrm{ST}<800$ & Sangat Baik \\
\hline
\end{tabular}

Dari tabel 7, dapat disimpulkan bahwa jumlah skor total 655 terdapat pada sikap skala tanggapan 544-672 dengan interpretasi baik.

Pada indikator yang menunjukkan sikap mahasiswa terhadap pembelajaran dengan menggunakan Pendekatan Realistic ada 10 
pernyataan. Diantaranya pernyataan 3 berjumlah 172 , pernyataan 4 berjumlah 167, pernyataan 10 berjumlah 160 , pernyataan 12 berjumlah 158 , pernyataan 14 berjumlah 166 , pernyataan 16 berjumlah 170 , pernyataan 18 berjumlah 143, pernyataan 20 berjumlah 159 , pernyataan 25 berjumlah 132, dan pernyataan 26 berjumlah 140, sehingga menghasilkan skor total sebesar 1567.

Tabel 8.

Skala Tanggapan terhadap Pendekatan Realistic

\begin{tabular}{|cc|}
\hline Skor Total $($ ST) & Interpretasi \\
\hline $400 \leq \mathrm{ST}<720$ & Sangat Jelek \\
\hline $720 \leq \mathrm{ST}<1040$ & Jelek \\
\hline $1040 \leq \mathrm{ST}<1360$ & Cukup \\
\hline $1360 \leq \mathrm{ST}<1680$ & Baik \\
\hline $1680 \leq \mathrm{ST}<2000$ & Sangat Baik \\
\hline
\end{tabular}

Dari tabel 8, dapat disimpulkan bahwa jumlah skor total 1567 terdapat pada sikap skala tanggapan 1360-1680 dengan interpretasi baik.

Pada indikator yang menunjukkan sikap mahasiswa terhadap soal-soal problem solving ada 6 pernyataan. Diantaranya pernyataan 5 berjumlah 150 , pernyataan 8 berjumlah 143, pernyataan 9 berjumlah 86 , pernyataan 15 berjumlah 131, pernyataan 17 berjumlah 151, dan pernyataan 21 berjumlah 164, sehingga menghasilkan skor total sebesar 825 .

Tabel 9.

Skala Tanggapan terhadap Soal Problem Solving

\begin{tabular}{|cc|}
\hline Skor Total $($ ST) & Interpretasi \\
\hline $240 \leq \mathrm{ST}<432$ & Sangat Jelek \\
\hline $432 \leq \mathrm{ST}<624$ & Jelek \\
\hline $624 \leq \mathrm{ST}<816$ & Cukup \\
\hline $816 \leq \mathrm{ST}<1008$ & Baik \\
\hline $1008 \leq \mathrm{ST}<1200$ & Sangat Baik \\
\hline
\end{tabular}

Dari tabel 9, dapat disimpulkan bahwa jumlah skor total 825 terdapat pada sikap skala tanggapan 816-1008 dengan interpretasi baik.

Pada indikator yang menunjukkan sikap mahasiswa terhadap soal-soal problem posing ada 6 pernyataan. Diantaranya pernyataan 2 berjumlah 172, pernyataan 6 berjumlah 144, pernyataan 13 berjumlah 133, pernyataan 19 berjumlah 110 , pernyataan 22 berjumlah 144, dan pernyataan 24 berjumlah 164, sehingga menghasilkan skor total sebesar 867.

Tabel 10 .

Skala Tanggapan terhadap Soal Problem Posing

\begin{tabular}{|cc|}
\hline Skor Total $($ ST) & Interpretasi \\
\hline $240 \leq \mathrm{ST}<432$ & Sangat Jelek \\
\hline $432 \leq \mathrm{ST}<624$ & Jelek \\
\hline $624 \leq \mathrm{ST}<816$ & Cukup \\
\hline $816 \leq \mathrm{ST}<1008$ & Baik \\
\hline $1008 \leq \mathrm{ST}<1200$ & Sangat Baik \\
\hline
\end{tabular}

Dari tabel 10, dapat disimpulkan bahwa jumlah skor total 867 terdapat pada sikap skala tanggapan 816-1008 dengan interpretasi baik.

Dari sisi lain, kita dapat melihat interpretasi sikap mahasiswa tiap individu pada kelas eksperimen. Pada data interpretasi skala sikap tiap individu mahasiswa kelas eksperimen terhadap pembelajaran matematika dengan menggunakan pembelajaran Pendekatan Realistic, soal-soal problem solving, dan soal-soal problem posing tergolong dalam interpretasi baik dan sangat baik.

\section{Penutup}

Berdasarkan hasil dari analisis data penelitian yang telah dikemukakan pada bagian sebelumnya diperoleh problem solving dan problem posing matematis mahasiswa selama mendapatkan pendekatan Realistic dan tradisional pada 
materi luas dan volum benda putar terhadap mahasiswa tingkat satu, salah satu institusi swasta di Bandung. Kesimpulannya adalah kemampuan problem solving dan problem posing matematis mahasiswa yang mendapatkan pendekatan Realistic lebih baik dibandingkan dengan kemampuan problem solving dan problem posing matematis mahasiswa yang mendapatkan pendekatan tradisional..

Selain simpulan yang telah dikemukakan sebelumnya, simpulan lain dalam penelitian ini adalah sebagai berikut:

1. Interpretasi peningkatan kemampuan problem solving matematis mahasiswa yang mendapatkan pendekatan Realistic dikatakan sedang dan pendekatan tradisional pun dikatakan sedang. Hal ini diperoleh dari hasil analisis gain ternormalisasi kemampuan problem solving matematis mahasiswa yang mendapatkan pendekatan Realistic memperoleh nilai rata-rata sebesar 0,57. Sedangkan hasil analisis gain ternormalisasi kemampuan problem solving matematis mahasiswa yang mendapatkan pendekatan tradisional memperoleh nilai rata-rata sebesar 0,40.

2. Interpretasi peningkatan kemampuan problem posing matematis mahasiswa pada kelas eksperimen dan kelas kontrol adalah sedang. Hal ini berdasarkan hasil analisis data gain ternormalisasi untuk kelas eksperimen nilai rata-ratanya sebesar 0,64 dan untuk kelas kontrol nilai rata-rata sebesar 0,40 yang keduanya berada pada interval yang berinterpretasi sedang.

3. Secara umum, interpretasi sikap mahasiswa yang mendapatkan pendekatan Realistic memiliki sikap yang baik terhadap pembelajaran matematika, pendekatan Realistic, dan persoalan problem solving dan problem posing matematis yang diberikan. Hasil interpretasi baik pun diperoleh apabila kita melihat pada tiap indikatornya. Kemudian, untuk interpretasi sikap mahasiswa tiap individu diperoleh baik dan sangat baik.

\section{UCAPAN TERIMA KASIH}

Terima kasih kepada para mahasiswa Teknik Sipil ITENAS angkatan 2015-2016 yang telah bersedia untuk menjadi subjek penelitian. Terima kasih pula peneliti sampaikan pada DIKTI sebagai sponsor dana penelitian melalui program Penelitian Dosen Pemula.

\section{DAFTAR Pustaka}

[1] H. L. Mikarsa, dkk, Pendidikan Anak di SD, Jakarta: Universitas Terbuka, 2005.

[2] Darta, Pembelajaran Matematika Konstekstual Dalam Upaya Mengembangkan Kemampuan Pemecahan Masalah dan Komunikasi Matematik Mahasiswa Calon Guru, Tesis Magister pada Sps UPI: Tidak diterbitkan, 2004.

[3] S. A. Chamberlin, (2015, Februari), What is Problem Solving in the Mathematics Classroom?, [online]. Tersedia: http://people.exeter.ac.uk/PErnest/po 
me23/Chamberlin\%20What20is\%20P rob\%20solving.doc, 2008.

[4] N. Kesumawati, Peningkatan Kemampuan Pemahaman, Pemecahan Masalah, dan Disposisi Matematik Siswa SMP Melalui Pendekatan Pendidikan Matematika Realistik, Disertasi Doktor pada SPs UPI: Tidak diterbitkan, 2010.

[5] D. Ismaimuza, Kemampuan Berpikir Kritis dan Kreatis Matematik Siswa SMP Melalui Pembelajaran Berbasis Masalah Dengan Strategi Konflik Kognitif, Disertasi Doktor pada SPs UPI: Tidak Diterbitkan, 2010.

[6] Hamzah, Meningkatkan Kemampuan Pemecahan Masalah Matematika Siswa Sekolah Lanjutan Tingkat Pertama Negeri di Bandung Melalui Pendekatan Problem Posing, Disertasi Doktor pada SPs UPI Bandung: Tidak Diterbitkan, 2003.

[7] N. F. Ellerton and P. C. Clarkson, Language factors in mathematics teaching and learning, International handbook of mathematics education, Springer Netherlands: 983-1033, 1996.

[8] NCTM, Principles and Standars for School Mathematics, Tersedia: http://www.nctm.org/standards/conten t.aspx?id=16909, 2000.

[9] E. A. Afriansyah, "Implementasi PMRI dalam Materi Sifat Komutatif dan Asosiatif pada Bilangan Bulat untuk Level Siswa SD/MI", Jurnal Pendidikan Matematika Musharafa Edisi 11 Tahun Ke-III, 19-25, 2012.

[10] E. A. Afriansyah, Design Research: Konsep Nilai Tempat dalam Operasi
Penjumlahan Bilangan Desimal di Kelas V Dekolah Dasar, Tesis Magister pada SPS UNSRIUTRECHT: Tidak diterbitkan, 2012.

[11] E. A. Afriansyah, "Design Research: Place Value in Decimal Numbers Using Metric System", International Seminar on Mathematics, Science, and Computer Science Education MSCEIS, Universitas Pendidikan Indonesia (UPI) Bandung, 2013.

[12] E. A. Afriansyah, "What Students' Thinking about Contextual Problem is", International Seminar on Innovation in Mathematics and Mathematics Education $\left(1^{\text {st }}\right.$ ISIMMED), Universitas Negeri Yogyakarta (UNY): Yogyakarta, 2014.

\section{Riwayat Hidup Penulis}

Ekasatya Aldila Afriansyah, M.Sc.. Lahir di Bandung, 4 April

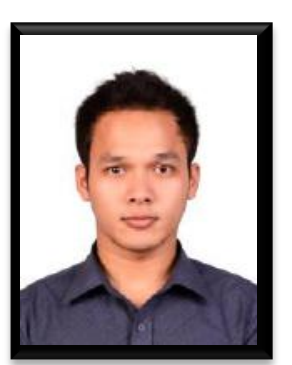

Palembang-Utrecht, lulus tahun 2012; dan S3 Pendidikan Matematika UPI, Bandung, sampai sekarang. 